\title{
IMAGEN 2-2016: Leishmaniasis visceral en Medula Ósea
}

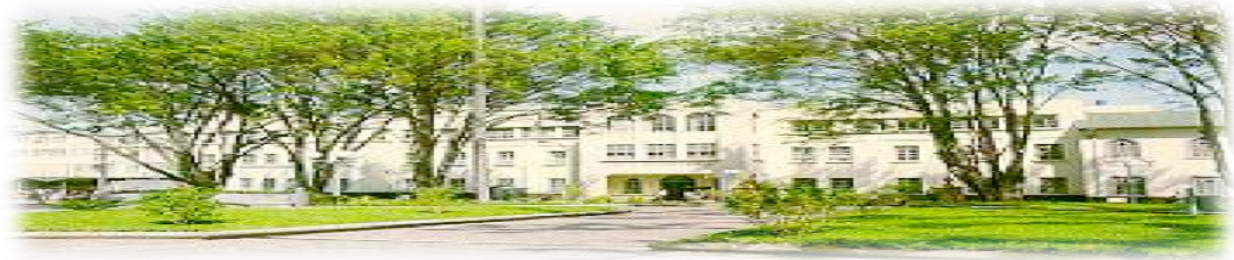

Hospital San quan de Dias. San Jasé, Casta Riua. Fundada en 1845

Recibido:

Aceptado:
$21 / 07 / 2014$

$14 / 04 / 2016$

Max A. Méndez López ${ }^{1}$ Jorge López Villegas ${ }^{2}$

${ }^{1}$ Médico Especialista en Hematología. Departamento de Hematología, Hospital Dr. RA Calderón Guardia, CCSS.maxmendez@runbox.com

${ }^{2}$ Microbiólogo Clínico, Especialista en Hematología. Departamento de Hematología, Hospital Dr. RA Calderón Guardia, CCSS.
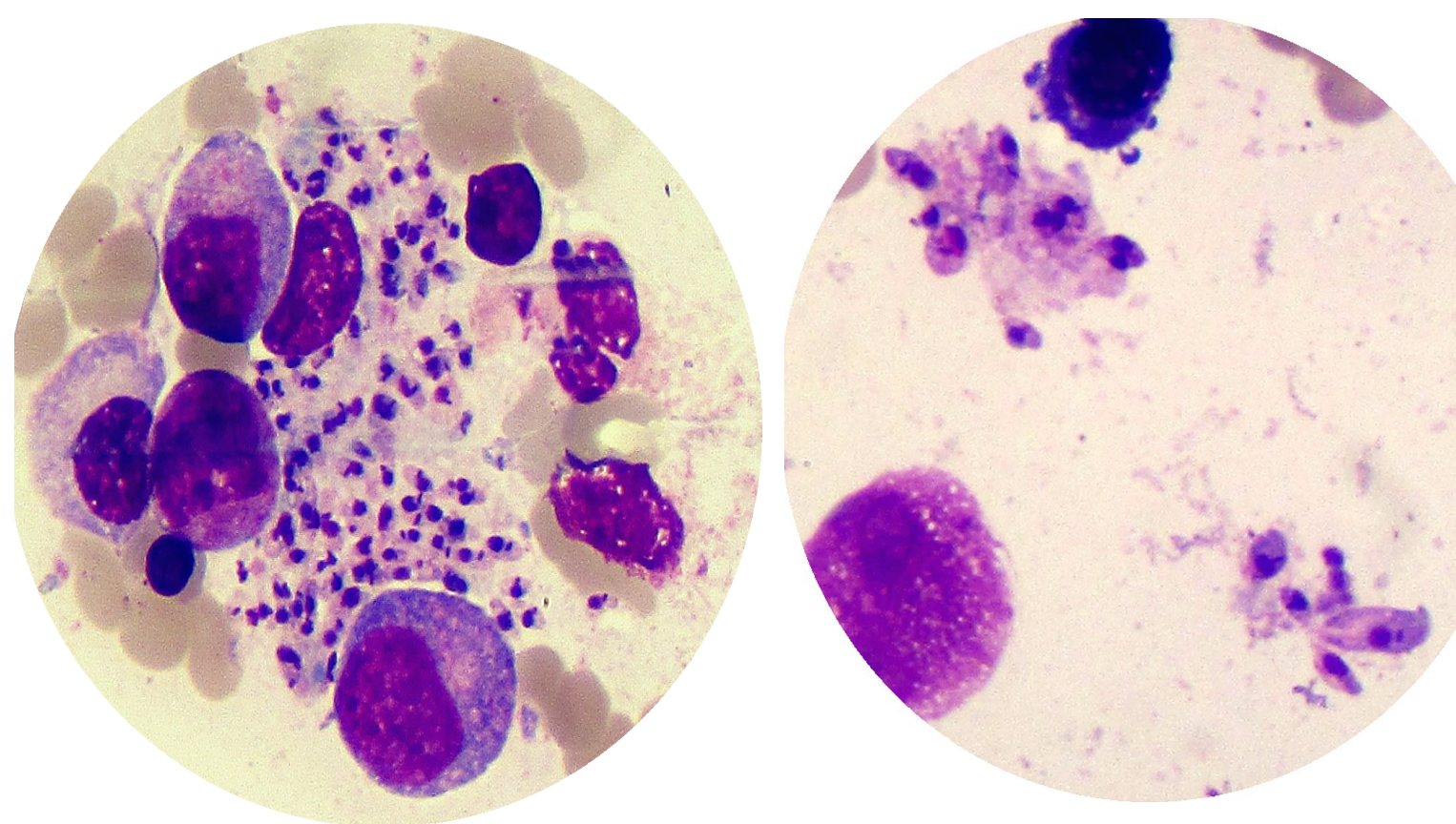

Láminas de paciente con Leishmania donovani. Histiocito fagocitando múltiples Leishmania (izquierda). Véase el kinetoplasto y la apariencia del núcleo en "doble punto" (flecha).

Fuente: CCSS 


\section{RESUMEN DEL CASO.}

Una mujer de 47 años, fue evaluada en Emergencias con fiebre y pancitopenia, con velocidad de eritrosedimentación en $160 \mathrm{~mm} / \mathrm{h}$ $(0-20 \mathrm{~mm} / \mathrm{h})$ y deshidrogenasa láctica en 980 U/L (140-280 U/L). Había sido diagnosticada VIH positiva desde hace 7 años y se mantenía con terapia antiretroviral hasta 6 meses atrás cuando decidió abandonar el seguimiento $\mathrm{y}$ medicación. A su llegada, el ultrasonido de abdomen documentó hepatoesplenomegalia sin adenopatías. Se puede apreciar en las imágenes un histiocito fagocitando múltiples leishmania (izquierda). El kinetoplasto y la apariencia del núcleo en "doble punto" (flecha) es de gran utilidad para la identificación morfológica de Leishmania donovani, confirmado posteriormente con cultivo de médula ósea. La diseritropoiesis y la plasmocitosis son frecuentes en estos pacientes y sumado a los efectos medulares del virus y los medicamentos, el cuadro es diagnóstico diferencial mandatorio de Síndrome Mielodisplásico. 


\section{BIBLIOGRAFÍA}

1. Singal R Gupta S. "Amyand's Hernia” Pathophysiology, Role of Investigations and Treatment. J. Clin. Med. 2011;6(4):321-327.

2. Michalinos A Moris D Spiridon V. Amyand's hernia: a review. Am J Surg. 2014;207:989-995

3. Kasper D Braunwald E Fauci A Hauser S Longo D Jameson J. Harrison's Principles of Internal Medicine. McGraw Hill Companies, Inc. New Cork - U.S.A. $16^{\text {th }}$ Edition, 2005.

4. Klatt E. Pathology of AIDS. Florida State University 2003;12:6-36 y 124-138.

\section{CONFLICTO DE INTERÉS Y/O AGRADECIMIENTOS}

Los autores declaran que no existió ningún conflicto de interés en el presente reporte. 